\title{
Hesperomyces virescens (Fungi, Ascomycota, Laboulbeniales) attacking Harmonia axyridis (Coleoptera, Coccinellidae) in its native range
}

\section{Citation}

Danny, Haelewaters, Richard F. Comont, Serena Y. Zhao, and Donald H. Pfister. 2014. “Hesperomyces Virescens (Fungi, Ascomycota, Laboulbeniales) Attacking Harmonia Axyridis (Coleoptera, Coccinellidae) in Its Native Range." Chinese Science Bulletin 59 (5-6) (January 29): 528-532. doi:10.1007/s11434-013-0060-1.

\section{Published Version}

doi:10.1007/s11434-013-0060-1

\section{Permanent link}

http://nrs.harvard.edu/urn-3:HUL.InstRepos:30168140

\section{Terms of Use}

This article was downloaded from Harvard University's DASH repository, and is made available under the terms and conditions applicable to Other Posted Material, as set forth at http:// nrs.harvard.edu/urn-3:HUL.InstRepos:dash.current.terms-of-use\#LAA

\section{Share Your Story}

The Harvard community has made this article openly available.

Please share how this access benefits you. Submit a story.

Accessibility 


\title{
Hesperomyces virescens (Fungi, Ascomycota, Laboulbeniales) attacking Harmonia axyridis (Coleoptera, Coccinellidae) in its native range
}

\author{
Haelewaters Danny • Richard F. Comont • \\ Serena Y. Zhao • Donald H. Pfister
}

Received: 1 July 2013/Accepted: 24 July 2013/Published online: 29 January 2014

(C) Science China Press and Springer-Verlag Berlin Heidelberg 2014

\begin{abstract}
This study intended to find data on obligate ectoparasitic Laboulbeniales (Fungi, Ascomycota) on Chinese Harmonia axyridis (Coleoptera, Coccinellidae). After having screened over four thousand dried specimens of $H$. axyridis and close relatives, we present the first (historical) record of Chinese $H$. axyridis infected with Hesperomyces virescens. We suggest that $H$. virescens is a historically globally distributed species and hypothesize that (native) infection was lost when $H$. axyridis was introduced in North America.
\end{abstract}

Keywords Coccinellidae - Distribution . Ectoparasitic fungi · Harmonia axyridis .

Hesperomyces virescens - Historical data - Invasive species - Native range

\section{Introduction}

Invasive species may drive native species to extinction by mating with closely related native species (hybridization), or through competition for resources or space, a more efficient use of available food resources, predation, and indirect effects $[1,2]$. Invasive "alien" species are now considered

H. Danny $(\bowtie) \cdot$ S. Y. Zhao $\cdot$ D. H. Pfister

Department of Organismic and Evolutionary Biology, Harvard University, 22 Divinity Avenue, Cambridge, MA 02138, USA e-mail: dhaelewaters@ fas.harvard.edu

\section{R. F. Comont}

NERC Centre for Ecology \& Hydrology, Maclean Building, Crowmarsh Gifford OX10 8BB, Oxfordshire, UK

\section{S. Y. Zhao}

Kraus Natural Science Building, University of Michigan, 830 North University, Ann Arbor, MI 48109, USA one of the top drivers of global biodiversity loss. A striking example of a deliberate introduction that has gone out of control is that of the multicolored Asian ladybird Harmonia axyridis (Pallas, 1773) (Coleoptera, Coccinellidae). H. axyridis is native to Asia between Siberia at the North and Southern China at the South, and from the Altai Mountains to the Pacific Ocean including Korea and Japan [3]. It was first introduced in North America in 1916 for biological control of agricultural pests such as aphids and scale insects on crops including citrus, maize, and tobacco [4, 5]. It has been reported in all but two US states [6]. In western Europe, $H$. axyridis was first introduced in 1982 in France and is now considered established in 26 European countries [6].

Many theories have been put forward to explain the success of invasive species. The enemy release hypothesis predicts that an invasive species in its new environment will experience a decrease in regulation by natural enemies, resulting in a competitive advantage for the alien species over native species [7, 8]. While it has been suggested [9] that there is no support of natural enemies exerting regulatory effects on coccinellid populations, a recent study provides an overview of parasites and pathogens with focus on the resilience of $H$. axyridis compared to other Coccinellidae [10].

Here, we consider the obligate ectoparasitic fungus $\mathrm{He}$ speromyces virescens Thaxt. (Ascomycota, Laboulbeniales). Previous work states that $H$. virescens does not attack $H$. axyridis in its native range $[10,11]$. We explore evidence available for assessing the (historical) distribution of $H$. virescens.

\section{Materials and methods}

Museum collections were examined for Laboulbeniales on $H$. axyridis, and close relatives that were selected based on recent 
phylogenies [12]: over four thousand dried specimens between 1915 and present were screened. The inspected entomological collections are deposited at the following institutions: National Museum of Natural History, Smithsonian Institution (1,274 specimens); Museum of Comparative Zoology, Harvard University (723 specimens); American Museum of Natural History (684 specimens); Field Museum (Chicago) (554 specimens); Department of Zoology, University of New Hampshire (513 specimens); Museum of Zoology, University of Michigan (314 specimens).

Parasitic thalli were carefully removed from the host integument using a BioQuip Minuten Pin and embedded in Amann solution [13]. Cover slips were ringed with transparent nail varnish. Morphological analyses and measurements were made using an Olympus BX40 light microscope with Olympus XC50 digital camera and MicroSuite Special Edition software 3.1 (Soft Imaging Solutions GmbH). Photography was done at the Harvard Center for Biological Imaging using a Zeiss AxioImager microscope running on ZEN software.

Microscopic slides are deposited at the United States National Fungus Collections (BPI) or at the Farlow Herbarium (FH), Harvard University.

\section{Results}

Of particular interest for this study was the discovery of Laboulbeniales parasitizing Chinese $H$. axyridis. Additional data resulting from the examination of the aforementioned entomological collections will be presented in subsequent papers.

A total of 1,152 $\mathrm{H}$. axyridis of 4,062 studied pinned ladybirds were listed, 336 of which had been collected in China. They were distributed among the Museum of Comparative Zoology, Harvard University (173 specimens); the National Museum of Natural History (159 specimens); and the Museum of Zoology, University of Michigan (4 specimens). From these examined specimens only two specimens, deposited at the National Museum of Natural History, were found infected with $H$. virescens.

\section{Taxonomy}

Hesperomyces virescens Thaxt., Proc Amer Acad Arts Sci 1891, 25: 264 (Fig. 1).

= Stigmatomyces virescens (Thaxt.) Thaxt., Proc Amer Acad Arts Sci 1894, 29: 106.

\subsection{Known distribution and hosts}

Described from California (as S. virescens) on Chilocorus stigma (Say 1835) (as Chilocorus bivulnerus; Coleoptera,

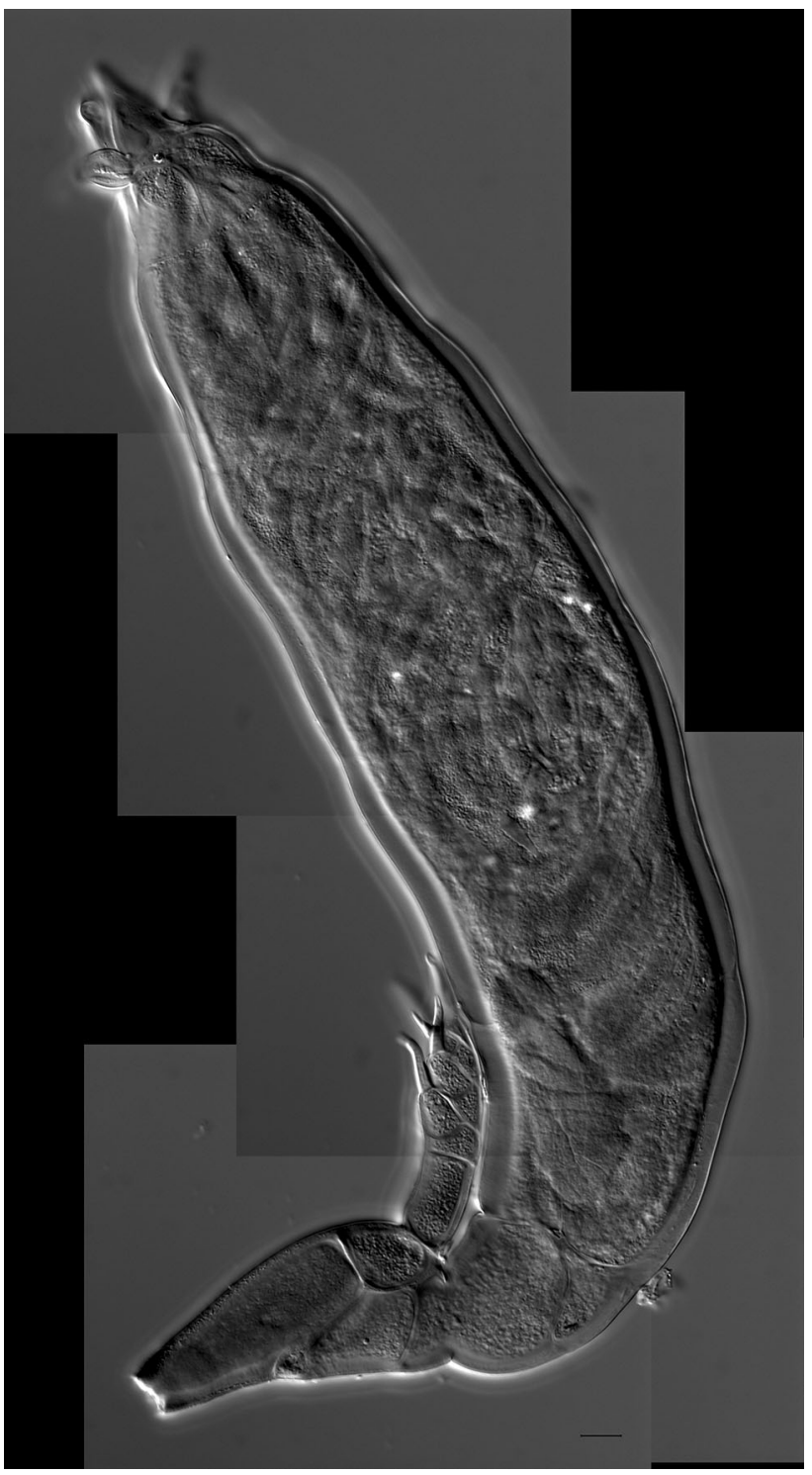

Fig. 1 Hesperomyces virescens Thaxt., mature thallus from left elytron of Chinese Harmonia axyridis (D. Haelew. 157a)

Coccinellidae), $H$. virescens is a widespread species known from all continents except Antarctica, attacking several coccinellid genera $[14,15]$. It has only been reported upon $H$. axyridis in the USA, Belgium, the Netherlands, Germany, and the UK; a detailed summary with all recordings of $H$. virescens on $H$. axyridis so far is given in Table 1 . In $H$. axyridis's native range, more specifically in Japan, $H$. virescens is reported parasitizing Coccinula crotchi (Lewis 1879) and C. sinensis (Weise 1889) [32].

\subsection{New chinese records of $H$. virescens on $H$. axyridis}

CHINA, Sichuan, Yibin, 10-14 Apr. 1930, leg. D.C. Graham, \# D.Haelew. 159, permanent slides D.Haelew. 159a (five specimens), 159b (three specimens), 159c (two 
Table 1 All published records of Hesperomyces virescens on Harmonia axyridis (adapted from [16])

\begin{tabular}{|c|c|c|c|}
\hline Region & Country & Year $(\mathrm{s})$ collected & Reference \\
\hline Sichuan Province & China & 1930-1939 & Present study \\
\hline Wayne County, Ohio & USA & 2002 & [17] \\
\hline Lebanon County, Pennsylvania & USA & $2002-2003$ & [18] \\
\hline Oktibbeha County, Mississippi & USA & 2003-2004 & [19] \\
\hline North Carolina & USA & 2003-2004 & {$[20]$} \\
\hline Harrison County, Kentucky & USA & 2004 & {$[21]$} \\
\hline Washington County, Arkansas & USA & 2005 & {$[22]$} \\
\hline Kentucky & USA & 2005 & {$[22]$} \\
\hline Payne County, Oklahoma & USA & 2005 & {$[22]$} \\
\hline Centre County, Pennsylvania & USA & 2005 & {$[22]$} \\
\hline Brookings County, South Dakota & USA & 2005 & {$[22]$} \\
\hline West Virginia & USA & 2005 & [22] \\
\hline Meise, Flemish Region & Belgium & 2006-2007 & [23] \\
\hline Peach County, Georgia & USA & 2007 & [24] \\
\hline Western Mississippi & USA & 2007-2009 & {$[25]$} \\
\hline De Kaaistoep, North Brabant & The Netherlands & 2008 & {$[26]$} \\
\hline Hessia & Germany & 2008-2009 & [27] \\
\hline De Kaaistoep, North Brabant & The Netherlands & 2008-2011 & [16] \\
\hline Hohenstein, Hessia & Germany & 2009 & [28] \\
\hline De Kaaistoep, North Brabant & The Netherlands & 2009 & [29] \\
\hline Zundert, North Brabant & The Netherlands & 2009 & [16] \\
\hline Ukkel, Brussels & Belgium & 2010 & [23] \\
\hline Giessen, Hessia & Germany & 2010 & {$[11]$} \\
\hline Peach County, Georgia & USA & 2009 & {$[30]$} \\
\hline Flemish Region & Belgium & 2011 & [23] \\
\hline De Kaaistoep, North Brabant & The Netherlands & 2011 & {$[31]$} \\
\hline Utrecht & The Netherlands & 2011 & {$[31]$} \\
\hline South East England & UK & 2011 & Present study \\
\hline Tilburg, North Brabant & The Netherlands & 2011 & Present study \\
\hline South Bohemian Region & Czech Republic & 2013 & {$[11]$} \\
\hline Destelbergen, Flemish Region & Belgium & 2013 & Present study \\
\hline
\end{tabular}

specimens), and 159d (three specimens)-all specimens collected from distolateral part of right elytron, in coll. BPI; Sichuan, no date, leg. D.C. Graham, \# D.Haelew. 157, permanent slide D.Haelew. 157a (three specimens collected from distomedian tip of left elytron), in coll. BPI.

\subsection{Remark}

The specimen \# D.Haelew. 157 is labeled with collector (D.C. Graham) and location (Sichuan, China), but without a date. From Graham's reconstructed field itinerary, we can infer that he collected ladybird specimens in the Sichuan region during the period from 1919 to 1939 . Within this timeframe, Graham completed fourteen summer expeditions to China, partly funded by the Smithsonian Institute
United States National Museum. Until 1948 he was affiliated with the West China Union University in Chengdu, capital of Sichuan province; afterwards he returned to the United States. Thus, any specimen collected by Graham in China most probably was collected during the period from 1919 to 1939 , in any case before 1948 .

\section{Discussion}

Roy et al. [10] suggest that $H$. virescens is probably native to North America, referring to the fact that Thaxter [33] first found it in the USA on C. stigma and Hippodamia convergens Guérin-Méneville, 1842, both native to North America [34]; soon more recordings from new localities 
extended the distribution of $H$. virescens to South America, Asia, and Oceania [35, 36]. The (historical) records for China of $H$. virescens parasitizing $H$. axyridis in this study give rise to the suggestion that $H$. virescens is a global species.

Although the first introduction of $H$. axyridis (of Japanese origin) in the USA happened in 1916 and despite at least fourteen reintroductions [4, 6], the first established population was only found in 1988, in Abita Springs, Louisiana [5]. Thereafter the species spread rapidly and currently is reported in all US states except for Alaska and Wyoming [6]. Microsatellite and mtDNA data show that the genetic structure in $H$. axyryidis in its native range falls into two groups, east and west, and that populations from both groups have contributed to the invasive, so-called bridgehead population in eastern North America [4, 6, 37]. This combination between genetically diverse populations from the native range may have facilitated the success of $H$. axyridis in North America, and consequently its subsequent expansion. It has been suggested that with the rapid expansion of $H$. axyridis also $H$. virescens will continue to spread globally [10] and threaten native, noninvasive Asian populations of $H$. axyridis [11].

While $H$. axyridis was already present in the USA in 1916, the earliest infected North American H. axyridis was found only during the summer of 2002 (in Ohio) [17], 86 years after the first introduction and 14 years after the first established population in the USA. Based on the presented records, we consider $H$. virescens a historically globally distributed species that also attacks $H$. axyridis in its native range. Furthermore, we hypothesize that native $H$. virescens infection was lost when beetles were imported into North America, for example, because sampled specimens were "clean" (free from infection) [37], and in line with the natural enemy release hypothesis [7, 8]. After a time lag reinfection with local $H$. virescens occurred, the first evidence of this was recorded in 2002 [17].

\section{Miscellaneous records of $H$. virescens}

Micronesia, Mariana Islands, Agrihan Volcano, 17 Jul. 1949, leg. D.B. Langford, on Harmonia octomaculata (Fabricius 1781), permanent slides D.Haelew. 160a-h (81 specimens, all collected from the elytra), in coll. BPI. USA, Alaska, Matanuska Valley, 27 Jul. 1944, leg. J.C. Chamberlin, on Hippodamia tredecimpunctata (Linnaeus 1758), permanent slides D.Haelew. 163a (ten specimens collected from distomedian tip left elytron), 163b (seven specimens collected from elytra), in coll. BPI; Alaska, Matanuska Valley, 29 Jun. 1944, leg. J.C. Chamberlin, on H. tredecimpunctata, permanent slides D.Haelew. 179a (five specimens collected from right metacoxa), 179b (seven specimens collected from sternum II), 179c (eight specimens collected from sternum III to IV), in coll. BPI; North Dakota, Grant County, Lake Tschida (Heart Butte Reservoir), 21 May 1966, leg. R.D. Gordon, on $H$. tredecimpunctata, permanent slides D.Haelew. 180a (twenty specimens collected from right elytron), $180 \mathrm{~b}$ (specimens collected from left elytron), in coll. BPI. UK, Oxfordshire, Sutton Courtenay, 10 Nov. 2011, leg. R.F. Comont, on H. axyridis, permanent slide FH 00313261 (five specimens collected from left elytron). The Netherlands, North Brabant, Tilburg, Nov. 2011, leg. B. Horvers, on $H$. axyridis, permanent slide FH 00313239 (over ten specimens collected from different body parts). BELGIUM, East Flanders, Destelbergen, town of Heusden, $\mathrm{N} 51^{\circ} 0^{\prime} 21.52^{\prime \prime}$ E3 ${ }^{\circ} 48^{\prime} 16.42^{\prime \prime}, 26$ Jun. 2013, leg. D. Haelewaters, on $H$. axyridis, permanent slide FH 00313262 (four specimens collected from third sternite).

Acknowledgments We wish to thank Piotr Ceryngier and Lidwien Raak-van den Berg for useful comments on the manuscript.

\section{References}

1. Blackburn TM, Cassey P, Duncan RP et al (2004) Avian extinction and mammalian introductions on oceanic islands. Science 305:1955-1958

2. Gaertner M, Den Bree A, Hui C et al (2009) Impacts of alien plant invasions on species richness in Mediterranean-type ecosystems: a meta-analysis. Prog Phys Geog 33:319-338

3. Koch RL, Venette RC, Hutchinson WD (2006) Invasions by Harmonia axyridis (Pallas) (Coleoptera: Coccinellidae) in the Western hemisphere: implications for South America. Neotrop Entomol 35:421-434

4. Gordon RD (1985) The Coccinellidae (Coleoptera) of America North of Mexico. J New York Entomol Soc 93:1-912

5. Chapin JB, Brou VA (1991) Harmonia axyridis (Pallas), the third species of the genus to be found in the United States (Coleoptera, Coccinellidae). Proc Entomol Soc Washington 93:630-635

6. Brown PMJ, Thomas CE, Lombaerts E et al (2011) The global spread of Harmonia axyridis (Coleoptera: Coccinellidae): distribution, dispersal and routes of invasion. Biocontrol 56:623-641

7. Colautti RI, Ricciardi A, Grigorovich IA et al (2004) Is invasion success explained by the enemy release hypothesis? Ecol Lett 7:721-733

8. Roy HE, Lawson Handley LJ, Schonrogge K et al (2011) Can the enemy release hypothesis explain the success of invasive alien predators and parasitoids? BioControl 56:451-468

9. Ceryngier P, Hodek I (1996) Enemies of Coccinellidae. In: Hodek I, Honěk A (eds) Ecology of Coccinellidae. Kluwer Academic Publishers, Dordrecht, pp 319-350

10. Roy HE, Rhule E, Harding S et al (2011) Living with the enemy: parasites and pathogens of the ladybird Harmonia axyridis. Biocontrol 56:663-679

11. Ceryngier P, Twardowska K (2013) Harmonia axyridis (Coleoptera: Coccinellidae) as a host of the parasitic fungus Hesperomyces virescens (Ascomycota: Laboulbeniales, Laboulbeniaceae): a case report and short review. Eur J Entomol 110:549-557

12. Magro A, Lecompte E, Magne F et al (2010) Phylogeny of ladybirds (Coleoptera: Coccinellidae): are the subfamilies monophyletic? Mol Phylogenet Evol 54:833-848 
13. Benjamin RK (1971) Introduction and supplement to Thaxter's contribution toward a monograph of the Laboulbeniaceae. Bibl Mycol 80:1-155

14. Santamaría S, Balazuc J, Tavares II (1991) Distribution of the European Laboulbeniales (Fungi, Ascomycotina). An annotated list of species. Treb Inst Bot Barcelona 14:1-123

15. Riddick EW, Cottrell TE, Kidd KA (2009) Natural enemies of the Coccinellidae: parasites, pathogens, and parasitoids. Biol Control 51:306-312

16. Raak-van den Berg CL, van Wielink PS, de Jong PW et al Invasive alien species under attack: natural enemies of Harmonia axyridis in the Netherlands. BioControl, accepted

17. Garcés S, Williams R (2004) First record of Hesperomyces virescens Thaxter (Laboulbeniales: Ascomycetes) on Harmonia axyridis (Pallas) (Coleoptera: Coccinellidae). J Kansas Entomol Soc 77:156-158

18. Riddick EW, Schaefer PW (2005) Occurrence, density, and distribution of parasitic fungus Hesperomyces virescens (Laboulbeniales: Laboulbeniaceae) on multicolored Asian lady beetle (Coleoptera: Coccinellidae). Ann Entomol Soc Am 98:615-624

19. Riddick EW (2006) Influence of host gender on infection rate, density and distribution of the parasitic fungus, Hesperomyces virescens, on the multicolored Asian lady beetle, Harmonia axyridis. J Insect Sci 6:1-15

20. Nalepa CA, Weir A (2007) Infection of Harmonia axyridis (Coleoptera: Coccinellidae) by Hesperomyces virescens (Ascomycetes: Laboulbeniales): role of mating status and aggregation behavior. J Invertebr Pathol 94:196-203

21. Harwood JD, Ricci C, Romani R et al (2006) Prevalence and association of the Laboulbenialean fungus Hesperomyces virescens (Laboulbeniales: Laboulbeniaceae) on coccinellid hosts (Coleoptera: Coccinellidae) in Kentucky. USA Eur J Entom 103:799-804

22. Harwood JD, Ricci C, Romani R et al (2006) Historic prevalence of a laboulbenialean fungus infected introduced coccinellids in the United States. Antenna 30:74-79

23. De Kesel A (2011) Hesperomyces (Laboulbeniales) and coccinellid hosts. Sterbeeckia 30:32-37

24. Riddick EW, Cottrell TE (2010) Is the prevalence and intensity of the ectoparasitic fungus Hesperomyces virescens related to the abundance of entomophagous coccinellids? Bull Insectol 63:71-78
25. Riddick EW (2010) Ectoparasitic mite and fungus on an invasive lady beetle: parasite coexistence and influence on host survival. Bull Insectol 63:13-20

26. Haelewaters D, De Kesel A. Laboulbeniales van De Kaaistoep D (2011) Natuurstudie in De Kaaistoep. In: Cramer T, van Wielink $\mathrm{P}$ (ed) 16e onderzoeksjaar. NV Tilburgsche Waterleiding-Maatschappij, KNNV-afdeling Tilburg \& Natuurmuseum Brabant, Verslag 2010, Amsterdam, pp 107-112

27. Herz A, Kleespiel RG (2012) Occurrence of natural enemies in different populations of the invasive ladybird Harmonia axyridis (Pallas, 1771) Coleoptera, Coccinellidae) in Germany. Mitt Dtsch Ges Allg Angew Entomol 18:201-206

28. Steenberg T, Harding S (2010) Entomopathogenic fungi found in field populations of the harlequin ladybird, Harmonia axyridis. IOBC/wprs Bull 58:137-141

29. Haelewaters D, van Wielink P, van Zuijlen JW et al (2012) New records of Laboulbeniales (Fungi, Ascomycota) for the Netherlands. Entomol Ber 72:175-183

30. Cottrell TE, Riddick EW (2012) Limited transmission of the ectoparasitic fungus Hesperomyces virescens between lady beetles. Psyche 72:1-100

31. Haelewaters D, Nuytinck J, De Kesel A (2012) Laboulbeniales (Fungi, Ascomycota) in the Netherlands: an introduction. Natuurh Maandblad 101:88-93

32. Ceryngier P, Roy HE, Poland RL (2012) Natural enemies of ladybird beetles. In: Hodek I, van Emden HF (eds) Ecology and behavior of the ladybird beetles (Coccinellidae). Blackwell Publishing Ltd, Hoboken, pp 375-443

33. Thaxter R (1891) Supplementary note on North American Laboulbeniaceae. Proc Amer Acad Arts Sci 25:261-270

34. Finlayson CJ, Alyokhin AV, Porter EW (2009) Interactions of native and non-native lady beetle species (Coleoptera: Coccinellidae) with aphid-tending ants in laboratory arenas. Environ Entomol 38:846-855

35. Spegazzini C (1917) Revisión de las Laboulbeniales Argentinas. An Mus Nac Hist Nat Buenos Aires 29:445-688

36. Thaxter R (1931) Contribution towards a monograph of the Laboulbeniaceae. Mem Amer Acad Arts Sci 16:1-435

37. Lombaert E, Guillemaud T, Cormuet JM et al (2010) Bridgehead effect in the worldwide invasion of the biocontrol harlequin ladybird. PLoS ONE 5:e9743 